\title{
An Analysis of Health Financial Protection in Ghana
}

Sataru Fuseini ( $\square$ fuseiniadams84@gmail.com )

World Bank Ghana https://orcid.org/0000-0002-4032-1330

Seddoh Anthony

World Bank Group

Kwame Twumasi-Ankrah

University of Bath

Research article

Keywords: Financial protection, health financing, health insurance, health inequities, prepayment

Posted Date: March 2nd, 2021

DOI: https://doi.org/10.21203/rs.3.rs-279476/v1

License: (c) (i) This work is licensed under a Creative Commons Attribution 4.0 International License. Read Full License 


\section{Abstract}

\section{Background}

Ghana introduced a state sponsored health insurance in 2005. The objectives of risk sharing through a prepaid mechanism was integral to the design, aimed at addressing the inequities in financial protection. Progress, however, has been predictably slow and complicated. The Scheme coexists alongside out-of-pocket spending, resulting in the persistence of catastrophic health expenditures and impoverishment. This study adds to the comparative literature on health financial protection in Ghana.

\section{Methods}

This study analysed data from Round 7 of the Ghana Living Standards Survey using ADePT. Out-of-pocket spending was used as the indicator for living standards. We estimated different headcount thresholds and concentration index for catastrophic health expenditure. Consumption was estimated to determine the poverty headcount and poverty gap. The distributive effect of health care expenditures on the different income quintiles was estimated to determine progressivity of health financing sources.

\section{Results}

Six percent of the households incurred catastrophic expenditures. The out-of-pocket health payments share reduced with total household resources. Those in the lowest quintile allocated a higher share of their total expenditures to health. This impoverished a significant proportion. The richer households had a higher share of health consumption. Therefore, the financing share rose the higher the quintile rank. The total redistributive effect of the expenditure on insurance, total expenditure on health and total payments showed an increase in income inequality between households. Expenditures on insurance and total health showed overall higher inequality for the bottom $25 \%$ and $50 \%$ of the population.

\section{Conclusion}

The results highlighted multiple technical challenges related to the implementation of policies and interventions on health financial protection. Ghana can leverage its Scheme to strengthen implementation of its current health financing policies and create opportunities for investments in pro-poor interventions and actions. Other supporting social protection strategies and policies can help reinforce the ability and flexibility of poor households to cope with the uncertainties of health expenditures.

\section{Background}

Globally on observations that most commentators have come to is that national health systems fail to provide adequate protection against the financial risks the population face in accessing health care [1-4]. This gap in access is evident in the 150 million people susceptible to financial catastrophe and a further 100 million thrown to poverty annually as a result of health care costs [5-7]. Many have called for the adoption of policies that advance access of health care services based on need, and not ability to pay and which subsequently does not result in financial ruin. The voices have found congruence in the mantra of Universal Health Coverage (UHC). Packaged as prepayment mechanisms to purchase a minimum package of essential services, UHC is an attractive policy and intervention $[2,5,6]$.

Ghana introduced a state sponsored health insurance in 2005, the National Health Insurance Scheme (NHIS). The Scheme has been extensively described in empirical literature [8-14]. The objectives of risk sharing through a prepaid mechanism was integral to the design [3, 4, 15-17], aimed at addressing the inequities in financial protection [18]. Progress, however, has been predictably slow and complicated [9, 12]. The prepayment system coexists alongside out-of-pocket (OOP) spending, resulting in the persistence of catastrophic health expenditures (CHEs) and impoverishment $[15,16,19]$. Building a strong and coherent body of literature on universal financial protection has been identified as critical in low- and middle-income countries (LMICs) especially $[4,20]$. Several studies have examined households health expenditures, impoverishment and inequalities in Ghana. This study adds to the comparative literature.

\section{Methods}

\section{Data source}

Data for this analysis is from the Ghana Living Standards Survey (GLSS) Round 7. Carried out between 2016 and 2017, the survey covered a nationally representative sample of 16,772 households. Detailed information collected on health, and insurance status, access of health care and health care expenditures is disaggregated by socio-demographic and -economic status [21].

\section{The Automated DEC Poverty Tables analysis tool}

The Automated DEC Poverty Tables (ADePT), a software package of the World Bank, has two modules for analysing household survey data. ADePT simplifies advanced technically challenging methods, facilitates replication of previous results and simplifies sensitivity analysis for 
results in accordance with underlying principles and assumptions of analysis. Issues such as programming errors associated with dissimilarities in computational methods are drastically reduced. This reduces variability thereby improving validity and authenticity of results. Module 2 of $\mathrm{ADePT}$, the health financing and financial protection - inclusive of catastrophic payments and impoverishing effects, and; progressivity and redistributive effect of health financing - was used for this analysis [22, 23].

\section{Analysis}

The GLSS 7 dataset was first prepared in Stata before uploading onto ADePT. The variables and analysis model is shown in Table 1. OOP spending was used as proxy for living standards. The analysis calculated the incidence of catastrophic OOP expenditure and impoverishment and its intensity. The progressivity of the sources of financing, that is OOP payments and social health insurance contributions, was also computed. In determining the decomposition effects of progressivity, horizontal equalty and reranking, the distributive effect of health financing, that is the effects of health care financing on income inequality, is also estimated [22, 23].

Table 1

The constructed health financial protection analysis model

\begin{tabular}{|c|c|c|c|c|c|c|}
\hline $\begin{array}{l}\text { Variables and } \\
\text { analysis }\end{array}$ & $\begin{array}{l}\text { Ability to pay } \\
\text { (consumption) }\end{array}$ & $\begin{array}{l}\text { OOP } \\
\text { payments }\end{array}$ & $\begin{array}{l}\text { Non-food } \\
\text { consumption }\end{array}$ & $\begin{array}{l}\text { Poverty } \\
\text { line }\end{array}$ & $\begin{array}{l}\text { Prepayments for } \\
\text { health care }\end{array}$ & $\begin{array}{l}\text { Data on health } \\
\text { financing mix }\end{array}$ \\
\hline \multicolumn{7}{|c|}{ Financial Protection } \\
\hline $\begin{array}{l}\text { Catastrophic } \\
\text { payments }\end{array}$ & $\checkmark$ & $\checkmark$ & $\checkmark$ & & & \\
\hline Impoverishment & $\checkmark$ & $\checkmark$ & & $\checkmark$ & & \\
\hline \multicolumn{7}{|l|}{ Progressivity and } \\
\hline \multicolumn{7}{|c|}{ redistributive effect } \\
\hline Progressivity & $\checkmark$ & $\checkmark$ & & & $\checkmark$ & $\checkmark$ \\
\hline $\begin{array}{l}\text { Redistributive } \\
\text { effect* }\end{array}$ & $\checkmark$ & $\checkmark$ & & & $\checkmark$ & $\checkmark$ \\
\hline \multicolumn{7}{|c|}{ Source: Wagstaff et al, 2011.} \\
\hline
\end{tabular}

\section{Catastrophic health spending}

OOP payments are direct household cash expenditures at the point of access that when they exceed the 15-20\% consumption threshold is deemed catastrophic $[15,16,22]$. OOPs are not necessarily always catastrophic [16, 24]. This threshold had a deterministic effect on the proportion of the population falling into this classification, also termed as the headcount. ADePT enabled head count simulations at different $\mathrm{CHE}$ thresholds for comparability and intensity (or overshoot). Catastrophic payments between the poor and rich households was differentiated by estimating the concentration index, where a negative index denotes higher CHEs among the poor and vice versa. By calculating the weighted head count index, we determined the degree of overshoot in relation to the place of households in income distribution. A negative concentration index being indicative of a higher weighted head count, vital in tracking CHEs among the poor [22].

\section{Impoverishment and health spending}

Health expenditures can be the difference between households either being well-off or poor. However, OOP spending as an indicator of household living standards totally neglects the opportunity cost of the forgone basic household necessities [3, 15, 22]. We aggregated consumption, inclusive and exclusive of OOP payments, to determine the alternate and actual scenarios. This showed the extent to which OOP payments contributed to the poverty headcount, including comparison of the poverty headcount with the two different consumption types. OOP payments intensify poverty among already poor households. To get the aggregated shortfall in consumption from the poverty line, we calculated the poverty gap attributable to OOP payments [22].

\section{Progressivity and redistributive effect}

In financial protection in health, equity is equally as important as CHEs and impoverishing health expenses. Health care expenditures by whatever means, voluntary or involuntary, has a deterministic effect on overall household expenditure. Where the health financing system is regressive, inequity in leftover income is high and vice versa. A rise implies progressivity and vice versa [22]. In analysing progressivity, as a share of households income, we estimated the effect of health care payments among the different income quintiles. Comparison of the income distribution, the Lorenz curve, and the distribution of health care payments, the payment concentration curve. is captured as the Kakwani's progressivity index. A higher uneven distribution in payments than income, with the payment concentration curve underneath the Lorenz curve, 
indicates progressiveness of health spending. However, a more balanced observation for payments than income, indicates health spending is regressive; the payment curve then sits on top of the Lorenz curve) [22].

A smaller prepayment Gini coefficient than the postpayment Gini coefficient signifies regressive health payments, and shows a higher degree in inequality in prepayment income distribution than for post-payment. A larger prepayment than post-payment Gini coefficient, however, is indicative of progressive payments and further suggestive of the balancing-off effect of health spending on income distribution. The difference between the two Gini coefficients confirms the magnitude of either the disequalizing or equalizing effect of health payments on income distribution. This is termed as the redistributive effect $[22,23]$ and is dependent on:

1. The Kakwani index; that is the progressivity of health care payments.

2. Health care payments as a proportion of income - where a higher percentage suggests a larger impact on income inequality.

3. The degree of horizontal inequality in; tax, social health insurance contributions, and OOP payments; as in comparable health care payments for households in the same rankings. Estimating horizontal inequality involved determining the post-payment income inequality for similarly ranked groups - a positive number - represented by $\mathrm{HI}$ in the equation below. The higher the degree of post-payment income inequality within groups, the higher the degree of horizontal inequity. The share of the population and post-payment income were weighted to determine the post-payment income inequality for each group. By either decreasing the equalizing or magnifying the disequalizing effects, horizontal inequalty diminishes the redistributive effect of health care payments.

4. The degree of reranking shows the different uses to which households distribute their residual income after health care payments. Stepwise, households within each group were first ranked by their prepayment income, followed by their post-payment income. The difference between the post-payment Gini coefficient and the post-payment concentration index afterwards showed the reranking [22, 23] as shown in the below equation:

$\mathrm{RE}=[\mathrm{g} /(1-\mathrm{g})]$ Kakwani $-\mathrm{HI}-$ Reranking

Where: RE is the difference between the two Gini coefficients, prepayment and post-payment incomes; $g$ represents the proportion of health spending of prepayment income; Kakwani represents equal household payments of equal ability in the Kakwani progressivity index; HI represents the horizontal inequalty index, and;

Reranking corresponds to the reranking index [23].

\section{Results}

\section{Households spending on health}

The dataset analysed from the GLSS covered health care expenditure for 14,009 households. Table 1 presents the summary expenditures by socio-demographic characteristics. Households in urban areas, for both gross and net per capita consumption, spent more than twice on health than rural households. The non-poor households similarly had a higher gross per capita consumption than the poor. Significant inequalities exists between the richer and poorer households as for example observed in total health payments between the Upper West, $6.2 \%$ on average, and Greater Accra, $33.4 \%$, regions. 
Table 1

Households expenditure on health by socio-demographic characteristics

\begin{tabular}{|c|c|c|c|c|c|c|}
\hline & $\begin{array}{l}\text { Per capita } \\
\text { consumption, } \\
\text { gross (GH区) }\end{array}$ & $\begin{array}{l}\text { Expenditure on } \\
\text { insurance, including } \\
\text { housing, health etc. (\%) }\end{array}$ & $\begin{array}{l}\text { Does (Name) pay premium } \\
\text { and/or processing fee to } \\
\text { become a member (\%) }\end{array}$ & $\begin{array}{l}\text { Total } \\
\text { expenditure } \\
\text { on health } \\
(\%)\end{array}$ & $\begin{array}{l}\text { Total } \\
\text { payments } \\
(\%)\end{array}$ & $\begin{array}{l}\text { Per capita } \\
\text { consumption, } \\
\text { net of payments } \\
\text { (GH区) }\end{array}$ \\
\hline \multicolumn{7}{|l|}{$\begin{array}{l}\text { Area of } \\
\text { residence }\end{array}$} \\
\hline Urban & 1817.3 & 4.3 & 0.1 & 27.3 & 31.6 & 1786.0 \\
\hline Rural & 549.8 & 0.5 & 0.0 & 15.5 & 16.1 & 534.2 \\
\hline \multicolumn{7}{|l|}{ Region } \\
\hline Western & 1051.9 & 0.7 & 0.0 & 17.0 & 17.8 & 1035.4 \\
\hline Central & 1138.9 & 5.3 & 0.0 & 27.9 & 33.2 & 1106.8 \\
\hline $\begin{array}{l}\text { Greater } \\
\text { Accra }\end{array}$ & 2279.3 & 3.4 & 0.1 & 29.9 & 33.4 & 2245.9 \\
\hline Volta & 689.3 & 2.0 & 0.0 & 25.4 & 27.5 & 661.8 \\
\hline Eastern & 1081.8 & 2.9 & 0.0 & 24.3 & 27.2 & 1054.5 \\
\hline Ashanti & 1813.4 & 2.1 & 0.1 & 24.2 & 26.3 & 1787.1 \\
\hline $\begin{array}{l}\text { Brong } \\
\text { Ahafo }\end{array}$ & 1000.8 & 0.5 & 0.1 & 9.6 & 10.2 & 990.6 \\
\hline Northern & 390.6 & 0.7 & 0.0 & 18.3 & 19.1 & 372.5 \\
\hline $\begin{array}{l}\text { Upper } \\
\text { East }\end{array}$ & 319.4 & 0.8 & 0.0 & 12.4 & 13.3 & 306.5 \\
\hline $\begin{array}{l}\text { Upper } \\
\text { West }\end{array}$ & 267.8 & 0.5 & 0.0 & 5.7 & 6.2 & 261.5 \\
\hline \multicolumn{7}{|l|}{$\begin{array}{l}\text { Is (Name) } \\
\text { Currently } \\
\text { Covered }\end{array}$} \\
\hline $\begin{array}{l}\text { Yes, } \\
\text { covered }\end{array}$ & 1183.6 & 2.2 & 0.5 & 24.0 & 26.6 & 1157.2 \\
\hline No & 946.1 & 1.4 & 0.0 & 20.4 & 21.8 & 924.9 \\
\hline \multicolumn{7}{|l|}{$\begin{array}{l}\text { Poverty } \\
\text { Status }\end{array}$} \\
\hline Poor & 134.4 & 0.0 & 0.0 & 269.7 & 269.7 & 0.0 \\
\hline Non-poor & 1001.4 & 1.9 & 0.0 & 19.0 & 20.9 & 980.5 \\
\hline Total & 998.9 & 1.9 & 0.0 & 19.7 & 21.6 & 977.7 \\
\hline
\end{tabular}

\section{Catastrophic health spending}

Table 2 presents measures of the incidence and intensity of catastrophic health payments. As the threshold increased from 5-25\% of total expenditure, the estimate of the incidence of catastrophic payments $(\mathrm{H})$ dropped from $24.2-6.2 \%$. Likewise the mean overshoot; from $4.2-1.6 \%$. The standard errors were small relative to the point estimates considering the large sample size. Unlike the headcount and the overshoot, the mean overshoot among those exceeding the threshold (MPO) need not decrease as the threshold is increased. Households who spent more than $5 \%$ of total expenditure on health on average spent $22 \%(5 \%+17.2 \%)$. Those that spent more than $25 \%$ of the household budget on health on average spent $51.2 \%$. For the different thresholds, both the head count and the overshoot were higher, when catastrophic payments are defined with respect to health payment relative to non-food expenditure. 
Table 2

Incidence and intensity of catastrophic health payments, threshold budget share

\begin{tabular}{|c|c|c|c|c|c|c|}
\hline & $5 \%$ & $10 \%$ & $15 \%$ & $25 \%$ & $30 \%$ & $40 \%$ \\
\hline \multicolumn{7}{|l|}{ Headcount $(H)$} \\
\hline Lowest quintile & 36.2 & 28.9 & 24.3 & 14.7 & 11.7 & 7.9 \\
\hline 2 & 27.4 & 17.4 & 13.7 & 6.9 & 5.6 & 3.0 \\
\hline 3 & 26.9 & 17.3 & 11.2 & 5.5 & 3.4 & 1.6 \\
\hline 4 & 20.1 & 11.8 & 6.1 & 2.6 & 1.9 & 0.8 \\
\hline Highest quintile & 10.3 & 5.5 & 2.8 & 1.5 & 1.2 & 0.5 \\
\hline Total & 24.2 & 16.2 & 11.6 & 6.2 & 4.8 & 2.8 \\
\hline \multicolumn{7}{|l|}{ Overshoot (O) } \\
\hline Lowest quintile & 9.9 & 8.3 & 6.9 & 5.1 & 4.4 & 3.4 \\
\hline 2 & 4.3 & 3.2 & 2.5 & 1.5 & 1.2 & 0.8 \\
\hline 3 & 3.6 & 2.5 & 1.8 & 1.1 & 0.9 & 0.6 \\
\hline 4 & 1.9 & 1.1 & 0.7 & 0.3 & 0.2 & 0.0 \\
\hline Highest quintile & 1.0 & 0.6 & 0.4 & 0.2 & 0.2 & 0.1 \\
\hline Total & 4.2 & 3.2 & 2.5 & 1.6 & 1.4 & 1.0 \\
\hline \multicolumn{7}{|c|}{ Mean positive overshoot (MPO) } \\
\hline Lowest quintile & 27.4 & 28.6 & 28.5 & 34.6 & 37.6 & 43.4 \\
\hline 2 & 15.8 & 18.6 & 18.1 & 21.4 & 20.7 & 25.2 \\
\hline 3 & 13.4 & 14.7 & 16.4 & 20.1 & 25.8 & 39.2 \\
\hline 4 & 9.6 & 9.7 & 11.4 & 11.6 & 9.9 & 5.9 \\
\hline Highest quintile & 9.7 & 11.5 & 15.0 & 14.6 & 12.9 & 14.2 \\
\hline Total & 17.2 & 19.6 & 21.3 & 26.2 & 28.5 & 35.8 \\
\hline
\end{tabular}

The total expenditure and non-food expenditure is illustrated in Fig. 1. For any budget share, the 00P or non-food expenditure curve is always to the right of the total expenditure curve. For more than $15 \%$ of households, health spending was at least one-fifth (1/5) of non-food expenditure, but health spending was about a quarter of total expenditure for $3 \%$ of households.

The concentration indices and rank-weighted headcount and overshoot measures are shown in Table 3. The distribution of catastrophic payments depends on whether health payments are expressed as a share of total expenditure or of non-food expenditure. In the former case, catastrophic payments decreased with total expenditure. It showed OOP health payments budget share reduced with total household resources. As a result, the rank-weighted headcount and overshoot were bigger than the unweighted indices shown in Table 2 . When the health payments were evaluated relative to non-food expenditure, it produced negative concentration indices, indicating households with low non-food expenditures were more likely to incur catastrophic health payments defined in this way. Consequently, the weighted indices are larger than the unweighted indices as shown in Table 4. 
Table 3

Threshold budget share

\begin{tabular}{|lllllll|}
\hline & $5 \%$ & $10 \%$ & $15 \%$ & $25 \%$ & $30 \%$ & $40 \%$ \\
\hline Using total expenditure & & & & & & \\
\hline Concentration index, C_E & -0.216 & -0.282 & -0.370 & -0.411 & -0.428 & -0.512 \\
\hline Rank-weighted headcount, H_W & 29.387 & 20.734 & 15.912 & 8.777 & 6.789 & 4.189 \\
\hline Concentration index, C_O & -0.409 & -0.458 & -0.497 & -0.549 & -0.574 & -0.616 \\
\hline Rank-weighted overshoot, O_W & 5.853 & 4.611 & 3.699 & 2.529 & 2.131 & 1.602 \\
\hline Using non-food expenditure & & & & & & \\
\hline Concentration index, C_E & -0.163 & -0.217 & -0.254 & -0.331 & -0.362 & -0.426 \\
\hline Rank-weighted headcount, H_W & 36.696 & 30.703 & 26.340 & 20.894 & 18.050 & 14.533 \\
\hline Concentration index, C_O & -0.403 & -0.431 & -0.457 & -0.497 & -0.514 & -0.541 \\
\hline Rank-weighted overshoot, O_W & 16.273 & 14.602 & 13.154 & 10.825 & 9.849 & 8.225 \\
\hline Source: Authors. & & & & & & \\
\hline
\end{tabular}

Table 4

Incidence and intensity of catastrophic health payments, using non-food, threshold budget share

\begin{tabular}{|c|c|c|c|c|c|c|}
\hline & $5 \%$ & $10 \%$ & $15 \%$ & $25 \%$ & $30 \%$ & $40 \%$ \\
\hline \multicolumn{7}{|l|}{ Headcount $(H)$} \\
\hline Lowest quintile & 43.0 & 37.7 & 34.7 & 29.9 & 26.8 & 23.4 \\
\hline 2 & 36.3 & 29.8 & 24.1 & 18.6 & 16.2 & 12.1 \\
\hline 3 & 32.9 & 27.2 & 22.6 & 16.4 & 12.9 & 9.5 \\
\hline 4 & 29.1 & 20.9 & 15.9 & 9.7 & 7.5 & 4.1 \\
\hline Highest quintile & 16.5 & 10.5 & 7.9 & 4.0 & 2.9 & 2.0 \\
\hline Total & 31.6 & 25.2 & 21.0 & 15.7 & 13.2 & 10.2 \\
\hline \multicolumn{7}{|l|}{ Overshoot (O) } \\
\hline Lowest quintile & 26.7 & 24.7 & 22.8 & 19.6 & 18.2 & 15.7 \\
\hline 2 & 12.6 & 11.0 & 9.6 & 7.5 & 6.6 & 5.2 \\
\hline 3 & 10.7 & 9.2 & 7.9 & 6.0 & 5.2 & 4.1 \\
\hline 4 & 5.6 & 4.4 & 3.4 & 2.1 & 1.7 & 1.2 \\
\hline Highest quintile & 2.5 & 1.9 & 1.4 & 0.9 & 0.7 & 0.5 \\
\hline Total & 11.6 & 10.2 & 9.0 & 7.2 & 6.5 & 5.3 \\
\hline \multicolumn{7}{|c|}{ Mean positive overshoot (MPO) } \\
\hline Lowest quintile & 61.9 & 65.3 & 65.8 & 65.7 & 68.0 & 67.3 \\
\hline 2 & 34.8 & 36.9 & 39.9 & 40.4 & 40.7 & 43.3 \\
\hline 3 & 32.4 & 33.7 & 35.0 & 36.5 & 40.8 & 43.6 \\
\hline 4 & 19.2 & 20.8 & 21.6 & 22.2 & 22.9 & 27.9 \\
\hline Highest quintile & 15.3 & 18.0 & 18.3 & 22.8 & 26.0 & 25.0 \\
\hline Total & 36.8 & 40.4 & 43.0 & 46.1 & 49.1 & 52.4 \\
\hline
\end{tabular}


Households in the lowest quintile allocated a higher share, $12.5 \%$, of their total expenditures to health. About three times the average spent by the top four quintiles (Fig. 2). The results further showed a 15\% incidence of OOP health payments. The effect of OOP payments on poverty using the Pen's parade of households based on their consumption expenditure distribution illustrated in Fig. 3 . The vertical bars shows for each household the extent to which the subtraction of OOP payments reduced consumption. Households pushed into poverty as a result of CHEs is $51.2 \%$ for those who spent more than $25 \%$ of their budget on health. The percentage population, headcount, pushed into poverty as a result of catastrophic payments dropped from $24.2-6.2 \%$ as the threshold increased from $5-25 \%$ of total expenditure. A substantial proportion of Ghanaian households were therefore impoverished by OOP payments. Simply put, those households that are near the poverty line, the horizontal red line, are impoverished as a result of incurring health expenditures.

\section{Progressivity and redistributive effect}

The per capita health care financing by households is shown in Table 5. The average per capita consumption by the poorest quintile, GH $\varangle 65.4$, was significantly lower than for the richest quintile, $\mathrm{GH} \otimes 3,725.70$. Expenditure on insurance, including housing and health, was mainly incurred by the richest. Poorer households in the lowest quintile incurred the least total health payments, GHख7.5 on average.

Table 5

Average per capita health finance

\begin{tabular}{|c|c|c|c|c|c|c|}
\hline & $\begin{array}{l}\text { Per capita } \\
\text { consumption, } \\
\text { gross (GH区) }\end{array}$ & $\begin{array}{l}\text { Expenditure on } \\
\text { insurance, including } \\
\text { housing, health etc. (\%) }\end{array}$ & $\begin{array}{l}\text { Does (Name) pay premium } \\
\text { and/or processing fee to } \\
\text { become a member (\%) }\end{array}$ & $\begin{array}{l}\text { Total } \\
\text { expenditure } \\
\text { on health } \\
(\%)\end{array}$ & $\begin{array}{l}\text { Total } \\
\text { payments } \\
\text { (\%) }\end{array}$ & $\begin{array}{l}\text { Per capita } \\
\text { consumption, net } \\
\text { of payments } \\
\text { (GH区) }\end{array}$ \\
\hline \multicolumn{7}{|c|}{ Quintiles of per capita consumption, gross } \\
\hline $\begin{array}{l}\text { Lowest } \\
\text { quintile }\end{array}$ & 65.4 & 0.2 & 0.0 & 7.3 & 7.5 & 58.9 \\
\hline 2 & 176.9 & 0.5 & 0.0 & 10.4 & 10.9 & 166.0 \\
\hline 3 & 342.5 & 0.2 & 0.0 & 17.9 & 18.1 & 325.6 \\
\hline 4 & 681.6 & 1.6 & 0.0 & 23.3 & 24.9 & 656.8 \\
\hline $\begin{array}{l}\text { Highest } \\
\text { quintile }\end{array}$ & $3,725.7$ & 6.9 & 0.1 & 39.5 & 46.5 & $3,679.3$ \\
\hline Total & 998.9 & 1.9 & 0.0 & 19.7 & 21.6 & 977.7 \\
\hline
\end{tabular}

Progressivity of households' health care financing is presented in Table 6 . It shows the average consumption and financing shares by quintiles with households ranked from lowest to highest of gross consumption. The information relating to consumption explains the inequality that exists between households in Ghana. The poorest quintile had the least share of consumption compared with the richest; from GH $₫ 1.3 \%$ to $\mathrm{GH} \otimes 74.6 \%$. The richest households paid a greater share, $46.8 \%$, in insurance premiums, than the poorest households. 
Table 6

Progressivity of health financing among households, shares of total financing

\begin{tabular}{|c|c|c|c|c|c|c|}
\hline & $\begin{array}{l}\text { Per capita } \\
\text { consumption, } \\
\text { gross (GH区) }\end{array}$ & $\begin{array}{l}\text { Expenditure on } \\
\text { insurance, including } \\
\text { housing, health etc. (\%) }\end{array}$ & $\begin{array}{l}\text { Does (Name) pay premium } \\
\text { and/or processing fee to } \\
\text { become a member (\%) }\end{array}$ & $\begin{array}{l}\text { Total } \\
\text { expenditure } \\
\text { on health } \\
(\%)\end{array}$ & $\begin{array}{l}\text { Total } \\
\text { payments } \\
(\%)\end{array}$ & $\begin{array}{l}\text { Per capita } \\
\text { consumption, } \\
\text { net of } \\
\text { payments } \\
(\mathrm{GHX})\end{array}$ \\
\hline \multicolumn{7}{|c|}{ Quintiles of per capita consumption, gross } \\
\hline $\begin{array}{l}\text { Lowest } \\
\text { quintile }\end{array}$ & 1.3 & 2.1 & 7.1 & 7.4 & 6.9 & 1.2 \\
\hline 2 & 3.5 & 5.0 & 12.3 & 10.6 & 10.2 & 3.4 \\
\hline 3 & 6.8 & 2.2 & 12.3 & 18.2 & 16.8 & 6.7 \\
\hline 4 & 13.7 & 16.8 & 21.6 & 23.7 & 23.1 & 13.4 \\
\hline $\begin{array}{l}\text { Highest } \\
\text { quintile }\end{array}$ & 74.6 & 73.9 & 46.8 & 40.2 & 43.1 & 75.3 \\
\hline Total & 100.0 & 100.0 & 100.0 & 100.0 & 100.0 & 100.0 \\
\hline $\begin{array}{l}\text { Gini } \\
\text { coefficient }\end{array}$ & 0.7040 & & & & & 0.7124 \\
\hline $\begin{array}{l}\text { Concentration } \\
\text { Index }\end{array}$ & & 0.6348 & 0.3783 & 0.3243 & 0.3512 & \\
\hline $\begin{array}{l}\text { Kakwani } \\
\text { index }\end{array}$ & & -0.0692 & -0.3257 & -0.3797 & -0.3529 & \\
\hline
\end{tabular}

Table 7 shows households' financing expressed as a share of their gross consumption. Tables 6 and 7 measure the financial concentration of households. The positive value of the Gini coefficient (0.7040) indicates the richer households had a higher share of health consumption. The Kakwani index explains progressivity, that is the difference between the concentration index and the Gini coefficient. The negative values for the Kakwani index shows the better-off households did not contribute more to the financing of health care than the poor.

Table 7

Progressivity of health financing among households, shares of total financing, budget shares

\begin{tabular}{|c|c|c|c|c|c|c|}
\hline & $\begin{array}{l}\text { Per capita } \\
\text { consumption, } \\
\text { gross (GH区) }\end{array}$ & $\begin{array}{l}\text { Expenditure on } \\
\text { insurance, including } \\
\text { housing, health etc.(\%) }\end{array}$ & $\begin{array}{l}\text { Does (Name) pay premium } \\
\text { and/or processing fee to } \\
\text { become a member (\%) }\end{array}$ & $\begin{array}{l}\text { Total } \\
\text { expenditure } \\
\text { on health } \\
(\%)\end{array}$ & $\begin{array}{l}\text { Total } \\
\text { payments } \\
\text { (\%) }\end{array}$ & $\begin{array}{l}\text { Per capita } \\
\text { consumption, } \\
\text { net of } \\
\text { payments } \\
(\mathrm{GHX)}\end{array}$ \\
\hline \multicolumn{7}{|c|}{$\begin{array}{l}\text { Quintiles of per capita } \\
\text { consumption, gross }\end{array}$} \\
\hline $\begin{array}{l}\text { Lowest } \\
\text { quintile }\end{array}$ & 100.0 & 0.3 & 0.0 & 11.1 & 11.4 & 90.0 \\
\hline 2 & 100.0 & 0.3 & 0.0 & 5.9 & 6.2 & 93.8 \\
\hline 3 & 100.0 & 0.1 & 0.0 & 5.2 & 5.3 & 95.1 \\
\hline 4 & 100.0 & 0.2 & 0.0 & 3.4 & 3.6 & 96.4 \\
\hline $\begin{array}{l}\text { Highest } \\
\text { quintile }\end{array}$ & 100.0 & 0.2 & 0.0 & 1.1 & 1.2 & 98.8 \\
\hline Total & 100.0 & 0.2 & 0.0 & 2.0 & 2.2 & 97.9 \\
\hline $\begin{array}{l}\text { Gini } \\
\text { coefficient }\end{array}$ & 0.7040 & & & & & 0.7124 \\
\hline $\begin{array}{l}\text { Concentration } \\
\text { Index }\end{array}$ & & 0.6348 & 0.3783 & 0.3243 & 0.3512 & \\
\hline $\begin{array}{l}\text { Kakwani } \\
\text { index }\end{array}$ & & -0.0692 & -0.3257 & -0.3797 & -0.3529 & \\
\hline
\end{tabular}


The lowest quintile accounted for, on average, $1.3 \%$ of total health consumption whereas the highest quintile consumed $74.6 \%$. Expenditure on insurance, including housing, health, among others, was mostly incurred by the richest households. The first three quintiles combined contributed just $9.3 \%$ on average. Therefore, the financing share rises the higher the quintile rank. Total expenditure on health represented $1.97 \%$ of the households budget, on average. The total redistributive effect of the expenditure on insurance $(-0.0002)$, total expenditure on health (-0.0069) and total payments $(-0.0071)$ showed an increase in households income inequality.

Table 8

Decomposition of redistributive impact of health care financing system

\begin{tabular}{|c|c|c|c|c|c|}
\hline & $\begin{array}{l}\text { Per capita } \\
\text { consumption, } \\
\text { gross (GH区) }\end{array}$ & $\begin{array}{l}\text { Expenditure on insurance, } \\
\text { including housing, health } \\
\text { etc. (\%) }\end{array}$ & $\begin{array}{l}\text { Does (Name) pay premium and/or } \\
\text { processing fee to become a } \\
\text { member (\%) }\end{array}$ & $\begin{array}{l}\text { Total } \\
\text { expenditure } \\
\text { on health }(\%)\end{array}$ & $\begin{array}{l}\text { Total } \\
\text { payments } \\
(\mathrm{GH囚})\end{array}$ \\
\hline \multicolumn{6}{|l|}{$\begin{array}{l}\text { Quintiles of per } \\
\text { capita consumption, } \\
\text { gross }\end{array}$} \\
\hline Lowest quintile & 1.3 & 2.1 & 7.1 & 7.4 & 6.9 \\
\hline 2 & 3.5 & 5.0 & 12.3 & 10.6 & 10.2 \\
\hline 3 & 6.8 & 2.2 & 12.3 & 18.2 & 16.8 \\
\hline 4 & 13.7 & 16.8 & 21.6 & 23.7 & 23.1 \\
\hline Highest quintile & 74.6 & 73.9 & 46.8 & 40.2 & 43.1 \\
\hline Total & 100.0 & 100.0 & 100.0 & 100.0 & 100.0 \\
\hline $\begin{array}{l}\text { Payments as } \\
\text { fraction of Income } \\
\text { (g) }\end{array}$ & 1.0000 & 0.0019 & 0.0000 & 0.0197 & 0.0216 \\
\hline $\begin{array}{l}\text { Kakwani index } \\
\text { assuming horizontal } \\
\text { equity (Ke) }\end{array}$ & 0.0000 & -0.3100 & -0.3121 & -0.3991 & -0.3912 \\
\hline Vertical effect (V) & 0.4898 & -0.0006 & 0.0000 & -0.0080 & -0.0086 \\
\hline $\begin{array}{l}\text { Horizontal inequality } \\
(H)\end{array}$ & -0.2142 & -0.0004 & 0.0000 & 0.0009 & 0.0005 \\
\hline Reranking (R) & 0.0000 & 0.0000 & 0.0000 & -0.0020 & -0.0020 \\
\hline $\begin{array}{l}\text { Total redistributive } \\
\text { effect }(\mathrm{RE}=\mathrm{V}-\mathrm{H}-\mathrm{R})\end{array}$ & 0.7040 & -0.0002 & 0.0000 & -0.0069 & -0.0071 \\
\hline V / RE & 0.6957 & 2.6375 & 0.9575 & 1.1680 & 1.2108 \\
\hline $\mathrm{H} / \mathrm{RE}$ & -0.3043 & 1.6375 & -0.0425 & -0.1270 & -0.0732 \\
\hline $\mathrm{R} / \mathrm{RE}$ & 0.0000 & 0.0000 & 0.0000 & 0.2950 & 0.2839 \\
\hline
\end{tabular}

The concentration curves for OOPs, Fig. 4, shows the expenditure on insurance, including housing, health, among others, as well as premium payments. The expenditure on insurance, premiums, and total health is farther away from the line of equality, indicative of higher inequality for the bottom $25 \%$ and $50 \%$ of the population. For instance, the bottom $25 \%$ spent $10 \%$ of their income on health. However, at $90 \%$ of the population, it corresponded to households with higher degree of equality. It shows that $90 \%$ of the population had a higher cumulative percentage of payments than the bottom $10 \%$.

\section{Discussion}

This analysis of households health care financing in Ghana showed significant findings that merit further attention. The finding of $15 \%$ incidence of OOP payments is within the recommended 15-20\% threshold, down from the pre-insurance level of $64 \%$ in 2002 [19, 25 ]. This is however evidently higher than the global average of 2.3\% [17]. Marked disparities still persist in incidence of OOP payments, ten times higher among uninsured households [13]. The $6.2 \%$ incidence of catastrophic payments is similarly broadly within the $1.3 \%-8 \%$ previously reported for Ghana $[8,10,13,21,26,27]$. Although an eight-fold reduction in incidence of CHEs has been recorded since 1995 [14], user fees remains the primary means by which poor Ghanaian households pay for health care, attributed to the low depth of prepayment coverage among this quintile $[9,13,14,28]$. Prepayment mechanisms also do not provide full immunity against OOP health expenditures $[1,8,17,29]$. Therefore the exclusion of specialised services from the Ghana Scheme's benefits package entrenches formal user fees, thus intensifying incidence of CHEs [9, 14, 28]. A 
more sustainable long-term policy goal, backed by related strategies, have to target reducing OOP spending as share of total health care financing among households in the bottom quintiles to lower than the $15 \%$ threshold. This may involve increasing the tax component of prepayment of the Scheme as a share of total expenditure on health. In general, this is of interest to developing countries implementing universal prepayment mechanisms $[17,26]$.

We further observed though households in the upper quintile paid more in insurance contributions as a share of total payments for health, the poorest paid highest. Premium contributions has previously been reported as a deterrent to insurance enrolment in Ghana $[10,11,13,30,31]$. Our negative values for the Kakwani index reaffirms findings by Akazili et al, Mills et al and Amporfu suggesting the better-off households do not contribute more to the financing of health care than the poor and that health care financing in Ghana is generally pro-rich $[9,10,21]$. The issue of regressive premium contributions pertains to the flat rates charged informal sector enrolees due to an inability of Scheme agents to actuarially determine the contributions for this group. It is also the case of the weak implementation of a free membership policy for the poor [8-10, 28]. This reiterates the importance of the need for periodic reviews of the price of insurance in poor resource settings and the introduction of caps for the different groups within the informal sector where necessary. Contributions to social health insurance (SHI) must therefore be based on ability to pay $[8,16,28,29]$. Other complementary policy options such as mixed targeting approaches improves the technical efficiency in identification, enrolment and extension of SHI coverage to vulnerable groups [8-10, 16, 29, 32]. Using poverty prevalence maps and profiles, a more ambitious policy and political dilemma will be to go universal altogether $[16,17,26,28,29]$. The first two options promote financial protection [9] and all three can potentially bridge inequity gaps in CHEs thereby offering more secured financial protection [10].

Households in the lower end and some in the middle half of the distribution were brought below the poverty line by health payments - that is $6.2 \%$ headcount - and that the poorest households had the highest share of expenditure allocation for health. This is consistent with the $3-5 \%$ and $9.4 \%$ headcount impoverishment arising from CHEs recently reported by Aryetey et al and Akazili et al [11,12]. This is suggestive of a strong correlation between OOPs, CHEs and impoverishment in Ghana, where health care expenditures trap and push vulnerable households deeper into poverty $[9,27,29]$. The adverse effects of prepayment policy reforms in poor resource settings include correlative effects with poverty and inverse care law where those who need health care the most access it the least $[15,19]$. Such reforms mainly involve the scrapping of OOP payments for consultation which is usually only a small fraction of the many other direct and indirect costs incurred $[1,15,33]$. Poor households therefore resort to coping mechanisms $[3,8,11,15]$. For instance, Levie and Xu found that for Ghanaian households in the highest category of inpatient spending, $40 \%$ resorted to borrowing and sale of assets to meet health care expenditures; the highest in a comparative study of eleven countries [3]. Ominously, some poor households simply forgo health care even though they need it to avoid the impoverishing costs [1, 15, 17, 25].

For financial protection to be truly universal and effective, it must go beyond the direct costs to include indirect costs and the elimination of other financial barriers that shape decision making on health [34-37, 38]. It is imperative that financial protection policies find support in transformative change in resource efficiency and expansionary budget policies to expand the domestic fiscal space for health $[3,16,28,33]$. Ghana and other developing countries can for instance learn from Indonesia, Sri Lanka and Malaysia where caps on user fees at public facilities and targeted exemptions for the poor have been effective in reducing impoverishment due to health spending [15]. A corresponding related strategy will involve introducing reimbursement policies for both direct and indirect household health expenditures for vulnerable groups [34].

The results also revealed deepening inequalities between households as a result of CHEs. Zhang et al reported a 5.4 percentage points' decrease in inequality in CHE in Ghana since 1995 [14]. While this represents creditable progress, it nevertheless should not distract from the still excessive socio-economic disparities between households attributable to health expenditures [10,14]. Such inequalities intensify the recurrence of the incurrence of CHEs any time poor households come into contact with the health system $[8,9,11,20]$. This highlights coverage and enrolment as poor indicators of financial protection [17] and an inability of the current systems of LMICs to adequately track and monitor the shifting dynamics in OOP spending and CHEs in general [37].

Remedial measures, therefore, should use a mix of policy and programmatic tools. Thailand's universal coverage programme used this approach to successfully reduce inequalities arising from health care costs $[8,17,24]$. The overarching strategy to tackling household inequalities due to health expenditures will require a broader human capital development approach that includes simultaneous strengthening of health and social services, and environments $[12,15,39]$ to build cross-cutting bi-directional synergies that link health and other development policies $[6,8,15]$. In this regard, enrolment of the poor in social security and poverty alleviation schemes [17, 24] and allocation of resources for health based on burden and need rather than cost-effectiveness and population, and facility density are more sustainable medium- to long-term policy strategies [33].

\section{Limitations}

The findings of this study should be discussed in respect of the following limitations. The data used for this analysis is from a national survey that required respondents recall information about households expenditures and consumption on health and the established period of recall can impact the information on the frequency and magnitude of health care payments thus affecting the actual occurrence of OOP spending and

Page $11 / 18$ 
CHEs $[37,39]$. The recall is also specific to a period of time hence does not allow for comparison of multiple health expenditures within the same households over a period of time - that is comparative analysis of multiple health expenditures for the same households over a period of time [24]. The type and number of variables included in the survey and the level of disaggregation impact the results, where higher levels of disaggregation tends to elevate estimates of health care expenditure. Hence, the number of expenditure categories and the period of recall used by the survey have a deterministic effect on the reliability and validity of households report on health spending [37]. Other supply- and demandside factors which determine availability and price of health care for which household expenditure data was not collected could have underestimated the composite household spending on health [16]. Importantly also, population level surveys on household spending like the GLSS tend to miss expenditures made to informal providers, including other associated indirect and direct costs in the course of health care seeking. This can underestimate OOP spending and CHEs $[9,16]$. The probability that households may become poorer as a result of the coping mechanisms they resort to and which may yet still not be captured as part of their spending on health as such expenditures are below the established threshold weakens the predictive power of OOP payments and CHEs as a measure of financial protection [12, 24, 25]. Obviously, not every household member that needs health care is able to access it due to financial limitations; these group assessments on CHEs and poverty tend to miss them $[16,20,24,25]$. Further, there is no golden standard for setting thresholds for financial catastrophe. This is usually subject to interpretations, adopted definition of OOP spending and CHEs used in the study and study objectives as is ours [20,40]. Finally, fidelity demands OOP payments and CHEs are analysed alongside utilisation data for a much clearer and complete representation [24].

These limitations notwithstanding, the methodologies used in this analysis are statistically proven, and used previously in a variety of studies in different contexts $[12,16,19,20,24,25,37,39,40]$. This study have assessed financial catastrophe and impoverishment at different thresholds which presents a broader picture on financial protection than any one threshold would have. In the absence of general guiding principles of calculating thresholds, based on the expenditure levels, this study nevertheless calculated multiple levels of thresholds for the different households thereby accounting for all possible scenarios [20].

\section{Conclusion}

Reflective pauses in the implementation of population level health policies and programmes such as for universal financial protection enable policy makers, programmers and scholarship alike to interrogate the evidence and evaluate the experiences and lessons learned. In Ghana's case, the results from this study, though mixed, are informative its health financing policies are failing to provide adequate financial protection against health expenditures for the poor. They further highlight the multiple technical challenges related to the operationalisation and rationalisation of policies and interventions on financial protection and risk equalization in poor resource settings in general. It is however pertinent that discussions on financial protection seek to magnify both the limitations and narrative of opportunities. This will require continuous understanding of the changing systemic and socio-demographic, and -economic factors that are amenable to financial catastrophe and push households into poverty.

Improving the ecosystem of the systemic and social determinants of health financing is central to any efforts targeted to financial protection in health. Following, Ghana can leverage its Scheme to strengthen the implementation of its current health financing policies and create opportunities for investments in pro-poor interventions and actions. This, when complemented by social protection strategies can reinforce and promote cross-sectoral policy and programmatic coherence to improve the ability and flexibility of poor households to cope with the uncertainties of health expenditures.

\section{Abbreviations}

\section{ADePT}

Automated DEC Poverty Tables; CHEs:Catastrophic Health Expenditures; GLSS:Ghana Living Standards Survey; LMICs:Low- and Middle-Income Countries; NHIS:National Health Insurance Scheme; OOP:Out-of-Pocket; SHI:Social Health Insurance; UHC:Universal Health Coverage

\section{Declarations}

\section{Authors' contributions}

FS conceived the study, analysed the data and drafted the manuscript. AS conceived the study and drafted the manuscript. KTA prepared and analysed the data. All authors read and approved the final manuscript.

\section{Funding}

This study did not receive funding.

\section{Availability of data and materials}


Data used in this study is available to the public at: http://www.statsghana.gov.gh/nada/index.php or https://open.africa/dataset/ghana-livingstandards-survey-glss-7-2017.

\section{Ethics approval and consent to participate}

Not applicable. This study does not involve human participants, human data or human tissue.

\section{Consent for publication}

Not applicable.

\section{Competing interests}

The authors declare that they have no competing interests.

\section{Acknowledgements}

Not Applicable

\section{Author Details}

${ }^{1}$ World Bank, King Hassan Rd, Plot No. 3, Independence Avenue, Ridge, Accra.

${ }^{2}$ University of Bath, Claverton Down, Bath, BA2 7AY, United Kingdom.

\section{References}

1. Xu K, Evans DB, Carrin G, Aguilar-Rivera AM. Designing Health Financing Systems to Reduce Catastrophic Health Expenditure. Technical Briefs for Policy-Makers, No. 2. WHO/EIP/HSF/PB/05.02. Switzerland. Geneva: World Health Organization; 2005.

2. World Health Organisation. Health Systems Financing: The path to universal coverage. The World Health Report. Switzerland: World Health Organization; 2010.

3. Leive A, Xu K. Coping with out-of-pocket health payments: empirical evidence from 15 African countries. Bull World Health Organ. 2008;86:849-56. doi:10.2471/BLT.07.049403.

4. Puteh SEW, Almualm Y. Catastrophic Health Expenditure among Developing Countries. Health Syst Policy Res. $2017 ; 4: 1$.

5. Global Burden of Disease Health Financing Collaborator Network. Trends in future health financing and coverage: future health spending and universal health coverage in 188 countries, 2016-40. Lancet. 2018;391:1783-98. doi.org/10.1016/S0140-6736(18)30697-4.

6. Chuma J, Maina T. Catastrophic health care spending and impoverishment in Kenya. BMC Health Services Research. 2012;12:413. http://www.biomedcentral.com/1472-6963/12/413.

7. Ottersen T, Norheim OF, et al. Making fair choices on the path to universal health coverage: Final report of the WHO Consultative Group on Equity and Universal Health Coverage. Switzerland, Geneva: World Health Organization; 2014. Available from: https://www.who.int/choice/documents/making_fair_choices/en/.

8. Nguyen HTH, Rajkotia Y, Wang H. The financial protection effect of Ghana National Health Insurance Scheme: evidence from a study in two rural districts. International Journal for Equity in Health. 2011;10:4. doi:10.1186/1475-9276-10-4.

9. Akazili J, Garshong B, Aikins M, Gyapong J, Mclntyre D. Progressivity of health care financing and incidence of service benefits in Ghana. Health Policy Plann. 2012;27:i13-22. doi:10.1093/heapol/czs004.

10. Amporfu E. Equity of the premium of the Ghanaian national health insurance scheme and the implications for achieving universal coverage. International Journal for Equity in Health. 2013;12:4. doi:10.1186/1475-9276-12-4.

11. Aryeetey GC, Westeneng J, Spaan E, Jehu-Appiah C, Agyepong IA, Baltussen R. Can health insurance protect against out-of-pocket and catastrophic expenditures and also support poverty reduction? Evidence from Ghana's National Health Insurance Scheme. International Journal for Equity in Health. 2016;15:116. doi:10.1186/s12939-016-0401-1.

12. Akazili J, Ataguba JEO, Kanmiki EW, Gyapong J, Sankoh O, Oduro A, Mclntyre D. Assessing the impoverishment effects of out-of-pocket healthcare payments prior to the uptake of the national health insurance scheme in Ghana. BMC International Health Human Rights. 2017;17:13. doi:10.1186/s12914-017-0121-7.

13. Okoroh J, Essoun S, Seddoh A, Harris H, Weissman JS, Dsane-Selby L, Riviello R. Evaluating the impact of the national health insurance scheme of Ghana on out of pocket expenditures: a systematic review. BMC Health Services Research. 2018;18:426.

doi.org/10.1186/s12913-018-3249-9. 
14. Zhang C, Rahman MS, Rahman MM, Yawson AE, Shibuya K. Trends and projections of universal health coverage indicators in Ghana,19952030: A national and subnational study. PLoSONE. 2019;14(5):e0209126. https://doi.org/10.1371/journal.pone.0209126.

15. van Doorslaer E, O’Donnell O, Rannan-Eliya RP, Somanathan A, Adhikari SR, Garg CC, Harbianto D, Herrin AN, Huq MN, Ibragimova S, Karan A, $\mathrm{Ng}$ CW, Pande BR, Racelis R, Tao S, Tin K, Tisayaticom K, Trisnantoro L, Vasavid C, Zhao Y. Effect of payments for health care on poverty estimates in 11 countries in Asia: an analysis of household survey data. Lancet. 2006;368:1357-64.

16. Xu K, Evans DB, Carrin G, Aguilar-Rivera AM, Musgrove P, Evans T. Protecting Households From Catastrophic Health Spending. Health Aff. 2007;26(4):972-83. doi:10.1377/hlthaff.26.4.972.

17. Wagstaff A, Flores G, Hsu J, Smitz MF, Chepynoga K, Buisman LR, van Wilgenburg K, Eozenou P. Progress on catastrophic health spending in 133 countries: a retrospective observational study. Lancet Glob Health. 2018;6:e169-79. http://dx.doi.org/10.1016/S2214109X(17)30429-1.

18. National Health Insurance Authority. National Health Insurance Scheme in Ghana: reforms and achievements. Accra: NHIA; 2013.

19. Qosaj FA, Froeschl G, Berisha M, Bellaqa B, Holle R. Catastrophic Expenditures and Impoverishment Due to Out-of-Pocket Health Payments in Kosovo. Cost Effectiveness Resource Allocation. 2018;16(1):26. https://doi.org/10.1186/s12962-018-0111-1.

20. Ngcamphalala C, Ataguba JE. An assessment of financial catastrophe and impoverishment from out-of-pocket health care payments in Swaziland. Global Health Action. 2018;11:1,1428473. doi:10.1080/16549716.2018.1428473.

21. Ghana Statistical Service. Ghana Living Standard Survey (GLSS 7) 2017. Available from: file://C:/Users/zeinab/Downloads/ddidocumentation-english-97.pdf file:///C:/Users/zeinab/Downloads/ddi-documentation-english-97.pdf. Accessed 21 Sept 2020.

22. Wagstaff A, Bilger M, Sajaia Z, Lokshin M. Health Equity and Financial Protection. Washington DC. The World Bank. 2011. Available from: https://openknowledge.worldbank.org/bitstream/handle/10986/2306/622580PUB0heal01476B0extop0id018459.pdf;sequence=1. Accessed 21 Sept 2020.

23. O’Donnell O, van Doorslaer E, Rannan-Eliya RP, Somanathan A, Adhikari SR, Harbianto D, Garg CG, Hanvoravongchai P, Huq MN, Karan A, Leung GM, Ng CW, Pande BR, Tin K, Trisnantoro L, Vasavid C, Zhang Y, Zhao Y. The Incidence of Public Spending on Healthcare: Comparative Evidence from Asia. World Bank Economic Review. 2007;21(1):93-123.

24. Wagstaff A, Flores G, Smitz MF, Hsu J, Chepynoga K, Eozenou P. Progress on impoverishing health spending in 122 countries: a retrospective observational study. Lancet Glob Health. 2017. http://dx.doi.org/10.1016/S2214-109X(17)30486-2.

25. Xu K, Evans DB, Kawabata K, Zeramdini R, Klavus J, Murray CJL. Household catastrophic health expenditure: a multicountry analysis. Lancet. 2003;362:111-17.

26. Zweifel P. 'Catastrophic' healthcare expenditure: critique of a problematic concept and a proposal. Eur J Health Econ. 2016;17:519-20. doi:10.1007/s10198-016-0761-x.

27. Mills A, Ataguba JE, Akazili J, Borghi J, Garshong B, Makawia S, Mtei G, Harris B, Macha J, Meheus F, Mclntyre D. Equity in financing and use of health care in Ghana, South Africa, and Tanzania: implications for paths to universal coverage. Lancet. 2012;380(9837):126-33. doi:10.1016/S0140-6736(12)60357-2.

28. Apoya P, Marriott A. Achieving a shared universal goal: free universal health Care in Ghana. OXFAM. 2011. Available from: http://policypractice.oxfam.org.uk/publications/achieving-a-shared-goal-free-universal-healthcare-in-ghana-125306.

29. Aryeetey GC, Jehu-Appiah C, Spaan E, D'Exelle B, Agyapong I, Baltussen R. Identification of poor households for premium exemptions in Ghana's National Health Insurance Scheme: empirical analysis of three strategies. Trop Med Int Health. 2010;15(12):1365-3156. doi:10.1111/j.1365-3156.2010.02663.x.

30. Jehu-Appiah C, Aryeetey C, Agyepong I, Spaan E, Baltussen R. Household perceptions and their implications for enrolment in the National Health Insurance Scheme in Ghana. Health Policy Plann. 2011;1-12; doi:10.1093/heapol/czr032.

31. Jehu-Appiah C, Aryeetey G, Spaan E, de Hoop T, Agyepong I, Baltussen R. Equity aspects of the National Health Insurance Scheme in Ghana: Who is enrolling, who is not and why? Soc Sci Med. 2011;72:157-65. doi:10.1016/j.socscimed.2010.10.025.

32. Aryeetey GC, Jehu-Appiah C, Spaan E, Agyapong I, Baltussen R. Costs, equity, efficiency and feasibility of identifying the poor in Ghana's National Health Insurance Scheme: empirical analysis of various strategies. Tropical Medicine International Health. 2011. doi:10.1111/j.1365-3156.2011.02886.x.

33. Saksena P, Xu K, Elovainio R, Perrot J. Health services utilization and out-of-pocket expenditure at public and private facilities in low-income countries. In: World Health Report (2010), Background Paper, 20. Switzerland. Geneva: World Health Organization; 2010.

34. Abiiro GA, De Allegri M. Universal health coverage from multiple perspectives: a synthesis of conceptual literature and global debates. BMC International Health Human Rights. 2015;15:17. doi:10.1186/s12914-015-0056-9.

35. Boerma T, AbouZahr C, Evans D, Evans T. Monitoring Intervention Coverage in the Context of Universal Health Coverage. PLoS Med. 2014;11(9):e1001728. doi:10.1371/journal.pmed.1001728. 
36. World Health Organisation, World Bank. Tracking universal health coverage: first global monitoring report. Switzerland, Geneva: World Health Organization. 2015.

https://apps.who.int/iris/bitstream/handle/10665/174536/9789241564977_eng.pdf;jsessionid=ED834052A2494549DF7A4F1DE22CF044? sequence=1. Accessed 20 Sept 2020.

37. Lu C, Chin B, Li G, Murray CJL. Limitations of methods for measuring out-of-pocket and catastrophic private health expenditures. Bull World Health Organ. 2009;87:238-44. doi:10.2471/BLT.08.054379.

38. Durairaj V, D'Almeida S, Kirigia J. Obstacles in the process of establishing a sustainable National Health Insurance Scheme: insights from Ghana. Background Paper No. 2. Switzerland. Geneva: World Health Organization; 2010.

39. van Doorslaer E, O’Donnell O, Rannan-Eliya RP, Somanathan A, Adhikari SR, Garg CC, Harbianto D, Herrin AN, Huq MN, Ibragimova S, Karan A, Lee TJ, Leung GM, Lu JFR, Ng CW, Pande BR, Racelis R, Tao S, Tin K, Tisayaticom K, Trisnantoro L, Vasavid C, Zhao Y. Catastrophic Payments for Health Care in Asia. Health Econ. 2007;16:1159-84. doi:10.1002/hec.1209.

40. Goryakin Y, Suhrcke M. The prevalence and determinants of catastrophic health expenditures attributable to non-communicable diseases in low- and middle-income countries: a methodological commentary. International Journal for Equity in Health. 2014;13:107. Available from: http://www.equityhealthj.com/content/13/1/107.

\section{Figures}

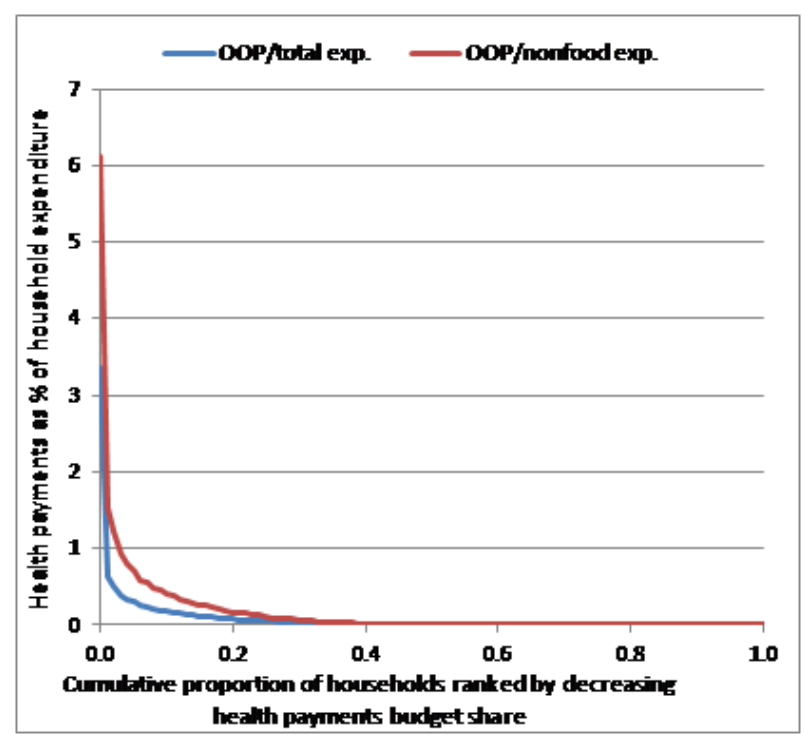

Figure 1

Health payment shares 


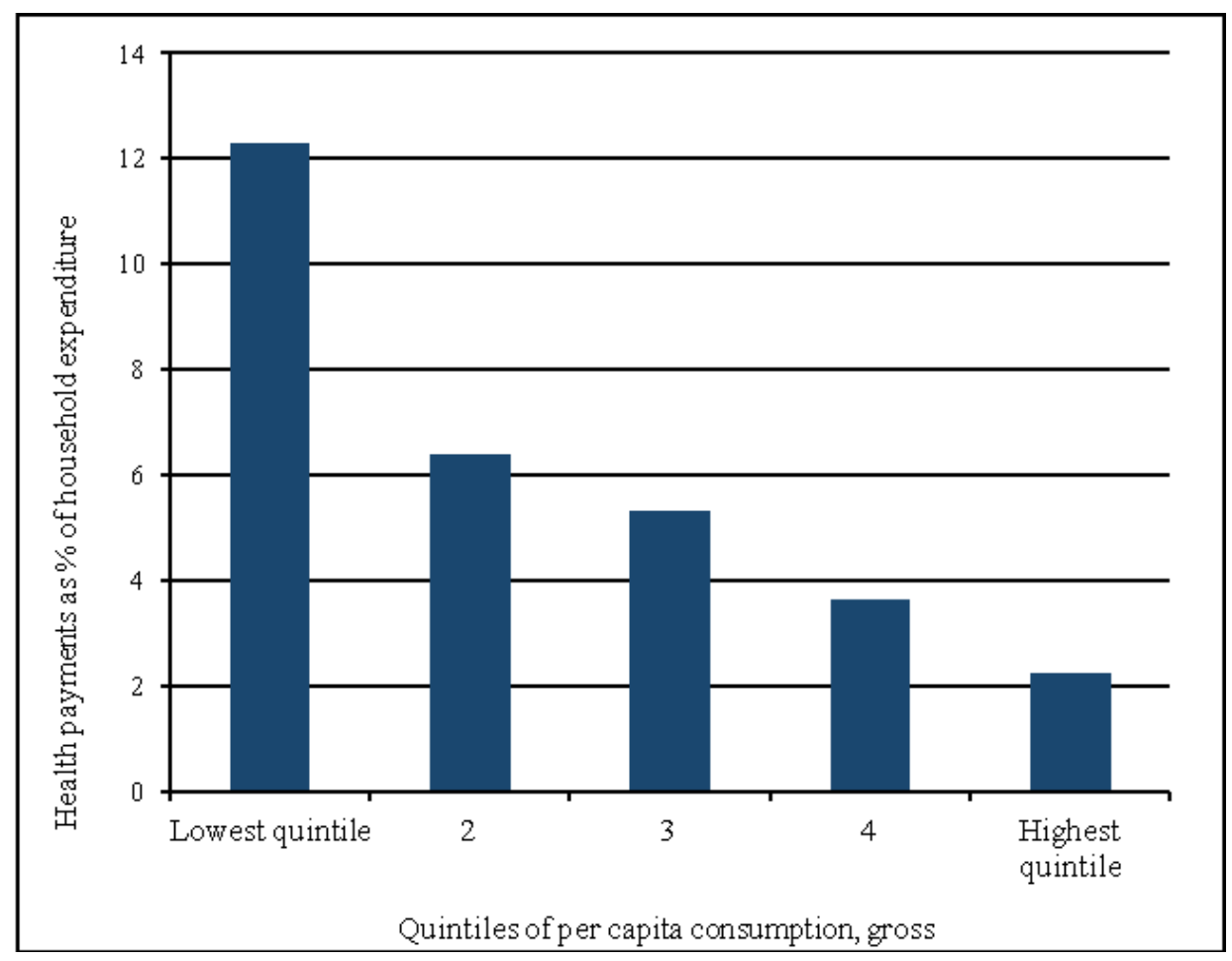

Figure 2

Health payment shares by quintiles 


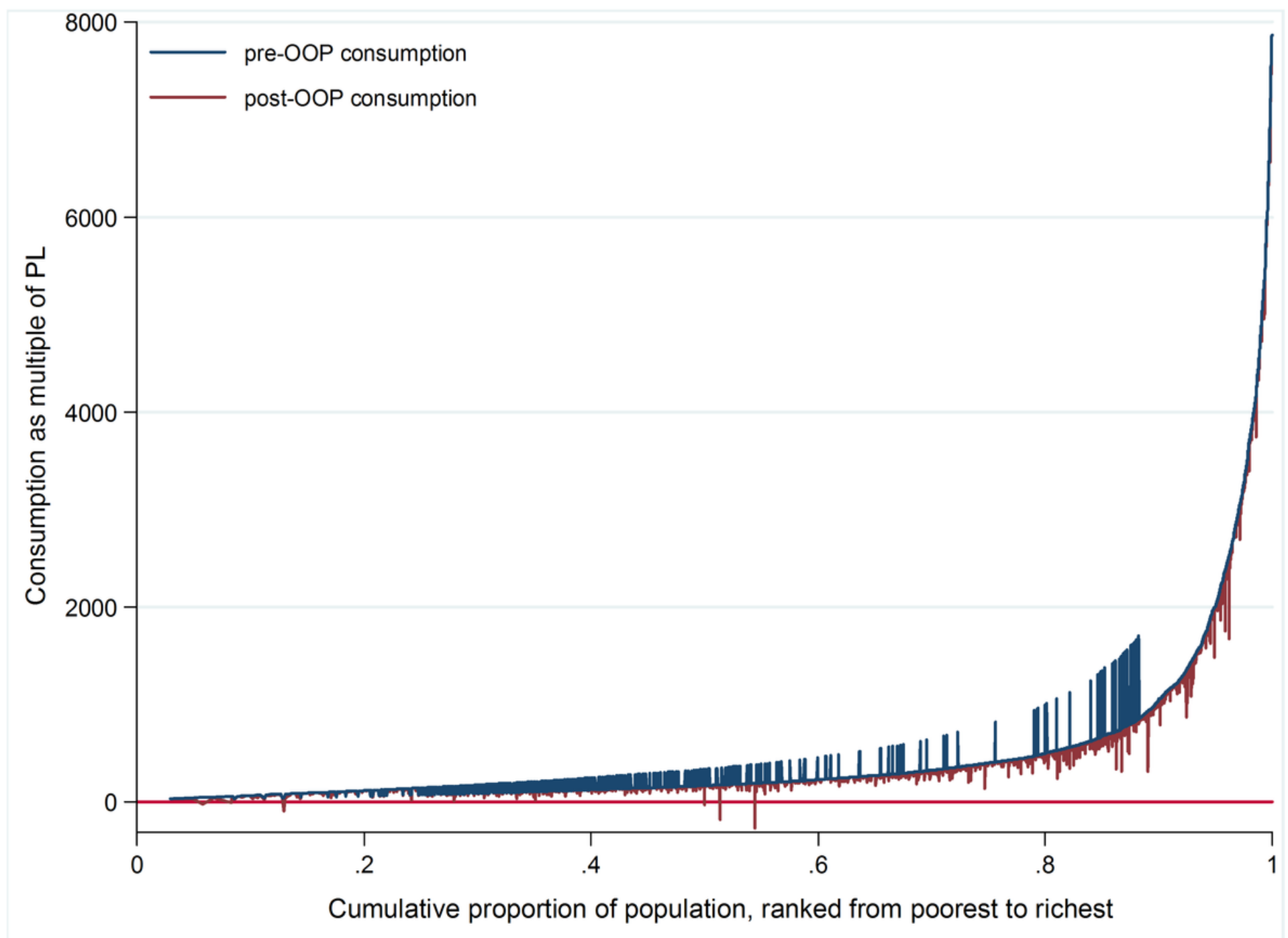

Figure 3

Effect of health payments on Pen's Parade of household consumption 


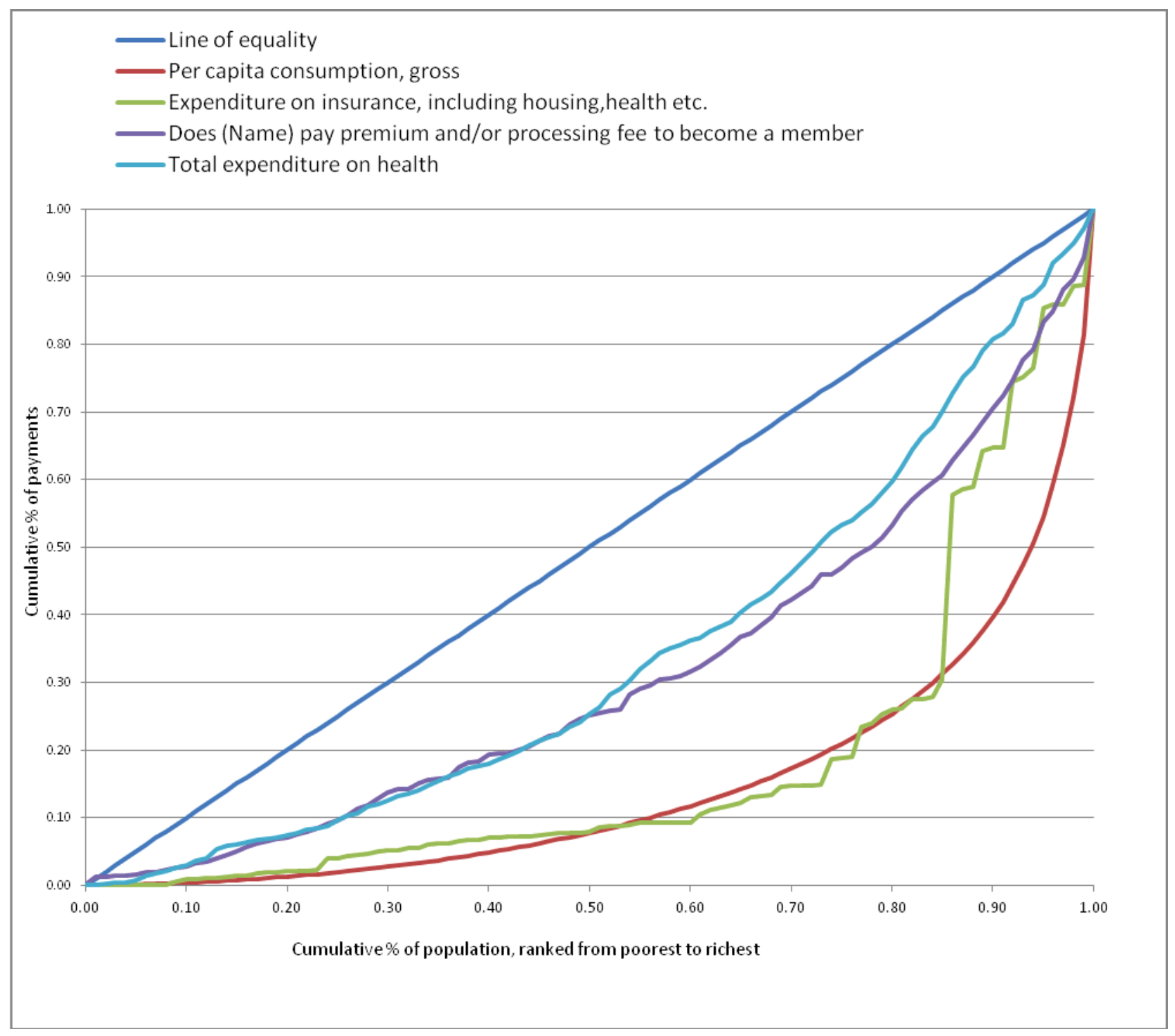

Figure 4

Concentration curves for health payments, insurance, OOP 